\title{
People
}

PROFILES

OCLC, Inc., announces the appointment of Dr. EDWARD T. O'NeILl, information scientist from the State University of New York at Buffalo, as Visiting Distinguished Scholar at OCLC. Dr. O'Neill is the first to hold the newly created post that annually will bring scientists to OCLC to conduct research in such fields as library science, computer science, applied mathematics, and industrial psychology.

Dr. O'Neill will begin his one-year appointment at OCLC in Columbus in September. He is on leave from the State University of New York at Buffalo, where he is associate professor in the School of Information and Library Studies and adjunct associate professor of industrial engineering. He received his $\mathrm{Ph} . \mathrm{D}$. in applied operations research and his master of science in industrial engineering from Purdue University.

As OCLC Distinguished Scholar Dr. O'Neill intends to conduct research focusing on subject access to large on-line data bases such as OCLC's. "We want to explore ways to get usable quantities of data with subject access," says Dr. O'Neill. "And the combination of computers, data base, and staff talent make OCLC an attractive choice for a sabbatical."

OCLC has six Xerox Sigma 9 computers, ten D-116 minicomputers, and two Tandem D/16 computers at its central facility in Columbus. Users at more than 2,200 remote terminals access OCLC's data base (about four-billion words) via dedicated, leased telephone lines.

OCLC's Visiting Distinguished Scholar Program is a twelve-month program. The appointee must have a $\mathrm{Ph}$. D. degree or equivalent training and substantial experience in directing and conducting research in fields of interest to OCLC. The V'isiting Scholar conducts research independently with no managerial or administrative duties, but is expected to interact closely with OCLC staff.

Ronald E. Diener has been appointed the first executive director of OHIONET. Diener is currently head of the Office for Systems Planning and Research at Harvard University Library. His educational background includes an A.B. from Northwestern College; A.M. University of Missouri (Columbia); B.D./M.Div., Concordia Seminary; and an M.S., Library Science, University of Illinois (Urbana). In November he will complete his Th. D. work at Harvard University, Divinity School.

In his present position, Diener is the administrative officer for university-wide computer sup- port systems at Harvard where such programs reside as CAPS, MCSS, HUL/CONSER, The Widener Shelflist Project, and the Widener Circulation System. Previous positions include planning officer for cooperative activities in the Harvard University Library; librarian, Boston Theological Institute; and executive director of the Center for Reformation Research

Recent activities in which Diener has been involved include member of the Systems and Technology Applications Committee of the Research Libraries Group; member of the Research Group's Task Force on an Automated Bibliographic Control System; member of the Executive Committee of the New England Library Information Network (NELINET); treasurer of NELINET and chairman of the Finance Committee; member of the OCLC Users Council (NELINET); and member of the CONSER Participants.

On December 1, 1978, Diener will assume his responsibilities, operating from OHIONET's new offices at 2929 Kenny Road, Columbus, Ohio.

EDWARD G. FERRANG, former media services librarian and instructor of library science with Newberry College, South Carolina, was recently appointed the director of the Learning Resources Center and assistant professor of librarianship with the University of New Mexico-Gallup Branch. While with Newberry College, he, along with his other duties, was the coordinator of a HEW Title I Program IMPACT Grant which investigated problems of the senior citizen in a series of videotape presentations, wrote an HEA Title VI-A Grant proposal for a closed circuit television distribution system, and developed an intercollegiate soccer program. He also served on the Advisory Board for the South Carolina Lung Association-Area Six Branch, and was active in the Jaycees and the South Carolina High School League as a basketball and baseball official.

A native of Pittsburgh, Pennsylvania, Ferrang received his $\mathrm{B}$.S. degree in education majoring in library science and secondary social studies from Edinboro State College, Pennsylvania, in 1972, and the master's degree in library science from the University of Pittsburgh's Graduate School of Library and Information Sciences in 1976. He also attended Newberry College and the University of South Carolina's Graduate School of Business Administration. He is a member of the American Library Association, the Association of College and Research Libraries, the Catholic Library Association, the Southeastern Library Association, and AECT of South Carolina. 


\section{CUMULATIVE INDEXES} OF THE FIRST KIND cover many years of one title

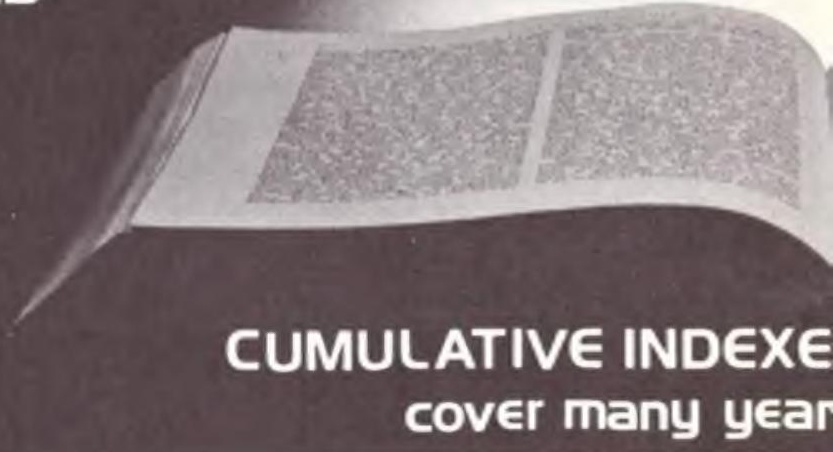

COMBINED RETROSPECTIVE INDEX TO JOURNALS IN

\section{HISTORY}

\author{
1838 - 1974
}

More than 150,000 articles from the backfiles of 234 History journais in the English Language have been indexed together and published in 9 casebound cumulative subject index volumes and 2 cumulative author index volumes. Articles were assigned to one or more of 336 hierarchical subject categories, and then computer sorted by keyword under each category to give in-depth specificity.

Eleven hardcover volumes .......\$1,095

Immediate Delivery

\section{COMBINED RETROSPECTIVE INDEX TO JOURNALS IN}

\section{POLITICAL SCIENCE}

1886 - 1974

This set contains 6 cumulative subject volumes and 2 cumulative author volumes. Coverage includes more than 115,000 articles on such topics as Politics, Public Administration and International Relations, from the backtiles of 179 English Language journals. Articles were assigned to one or more of 95 hierarchical subject categories, and then computer sorted by keyword under each category to give indepth specificity.

Eight hardcover volumes ......... \$825 Immediate Delivery
CUMULATIVE SUBJECT INDEX

TO THE MONTHLY CATALOG OF

\section{U.S. GOVERMIMENT PUBLICATIONS}

$$
1900 \cdot 1971
$$

The largest and most comprehensive retrospective subject index to U.S. Government Publications ever produced. Already at work in libraries throughout the world, it has received excellent reviews and was selected in Best Reference Books, 1970-1976. Also available are reprints of the Monthly Catalog itself from 1895-1962, including 30 volumes to which previously missing Superintendent of Documents Class Numbers were added.

Fifteen hardcover volumes ........\$1,160

Immediate Delivery
CUMULATIVE SUBJECT INDEX

TO THE ANNUAL CATALOGUES OF

\section{HER MAJESTY'S STATIONERY OFFICE PUBLICATIONS \\ 1922 - 1972}

Here is a single source of bibliographic access to 51 years of British Government documents - with unique coverage of both Parliamentary and NonParliamentary publications. Copies of the Annual Catalogues and a 12 million page collection of the documents themselves are also available on microfilm.

Two hardcover volumes .......... \$195 Immediate Delivery 


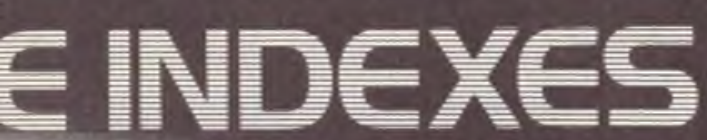

\section{CUMULATIVEINDEXES OF THE SECOND KIND cover one year of many titles}

\section{OF THE THIRD KIND of many titles}

\section{COMBINED RETROSPECTIVE INDEX TO JOURNALS IN

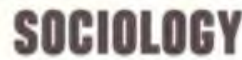 \\ 1895 - 1974}

From the retrospective collections of 118 English Language sociology journals, some 105,000 articles have been indexed and their entries interfiled in five casebound folio-size cumulative subject volmes, and one cumulative author index volume. Articles were assigned to one or more of 87 hierarchical subject categories, and then computer sorted by keyword under each category to give in-depth specificity.

Six hardcover volumes ........... \$615

Immediate Delivery

\section{COMBINED RETROSPECTIVE INDEX TO BOOK REVIEWS IN \\ SCHOLARLY JOURMALS}

\section{6 - 1974}

From the complete backfile runs of 472 scholarly journals in History, Political Science, and Sociology (whose articles were indexed in the other three CRIS Indexes) comes this single source of author/ title access to more than 1.2 million book reviews the majority of which have never before been covered in any book review index. Compiled by Evan Ira Farber.

Fifteen hardcover volumes ....... \$1,232*

$$
\text { *Prepublication Price }
$$

\section{CUMULATIVE SUBJECT INDEX TO THE \\ P.A.I.S. AMNUAL BULLETINS}

1915 - 1974

The Public Affairs Information Service offers selective coverage of a full spectrum of printed materials in its major fields of interest, namely 20th Century Economics, Political Science, and International Relations. More than 1,000 periodicals are covered as are monographs, government documents, and special reports. Now the P.A.I.S. Bulletin will have a single source of subject access for its entire 60 year run. Also available are reprints of the Bulletins themselves.

Fifteen hardcover volumes ....... \$1,182

Immediare Delivery

ACH OF THESE IMPORTANT INDEX SETS. DAIVE, ARLINGTON, VIRGINIA 22209
CUMULATIVE SUBJECT GUIDE TO

\section{U.S. GOVERMMENT BIBLIOGRAPHIES \\ $1924 \cdot 1973$}

More than 40,000 complete entries describing More than were taken from 50 years of the Monthly Catalog of U.S. Govern by subject, and arranged alphabetically of Documents nexed by SuperintendentClassification Number. contained bibliographies whided bibliographies 22,000 entries describe adden have never befch have

and "lists of references" whibliographies. Seven hardcover volumes immediate Delivery 


\section{APPOINTMENTS}

Sally HaRriet Bennett-cataloger/reference librarian-Eastern College. St. David's, Pennsylvania.

JUDITH BERNSTEIN-temporary reference librarian-University of NEW MExico. Albuquerque.

Gil Chestnut-assistant librarian-Bethel College. McKenzie, Tennessee.

Erika M. Condon-library director-Mount St Mary's College. Los Angeles, California.

Caroline Coughin-assistant directorDrew University, Madison, New Jersey.

Anita L. Cristan-monographs cataloger, Latin American Collection-Uviversitr of TEXAS AT AUSTIN.

Jay Cunningham-assistant chief of state library services-Califorila State Library, Sacramento.

Mina Daniels - assistant director, technical services-STATE UNIVERSTY OF NEW YORK AT ALBANY

Patrice I. Felder-serials cataloger, Latin American Collection-UNIVERSITY of TEXAS AT AustiN.

EILeEN Mary Gallagher-assistant librarian-Felician College. Chicago, Illinois.

Roger Gifford-senior analyst/programmer-State UNIVERSITY of NeW YoRK at AlbayY.

ConNIE HILL-catalog librarian-UNIVERSITY of Wisconsin-Stout, Menomonie.

ANDREA HINDING-director, Walter Library-UNIVERSITY OF MINNESOTA. Minneapolis.

RALPH HoPP-director, Institute of Technology Libraries-Univensity of Minnesota, Minneapolis.

Phebe KinkhaM-reference librarian-PhILlips UNIYERSITY, Enid, Oklahoma.

ANNE LATTA-special collections librarianState UNIVERSTTY OF NEW YORK AT ALBANY

Bobbye L. McCarter-head librarianBethel College. McKenzie, Tennessee.

RUSSELL MERRITT-record cataloger/reference librarian-STATE UNIVERSITY OF NEW YORK AT Buffalo.

Mary Miller-assistant for technical services-STATE UNIVERITY OF NEW YORK AT BUFFALO

Edward OetTIng-archivist-STate Univer. SITY OF NEW YORK AT ALBANY

Jehry Persons-music librarian-Stanford UNIVERSITY. California.

Alan K. Rome-assistant engineering librarian-UNIVERSITY OF TEXAS AT ALSTIN.

Robert S. RunYon-director-UnIVERSITY OF NEbraska AT OMaHA

RITA RYUN-reference librarian-UNIVERSITY OF Wisconsin.Stol't, Menomonie.

Susan Sarno-head librarian-Califoria School of Professional Psychology. Los Angeles.
VAndolyn J. Savage-assistant director for technical services-UNIVERSITY OF HOUSTON, Texas.

Patrice Schifter-assistant librarianCalifornia School of Professional PsycholOGY, Los Angeles.

Thomas W. Shauchnessy-assistant director for public services and collection development-Univensity of Houston. Texas.

Barbara SIEH-catalog librarian-UNIVERSITY of Wisconsin-STout Menomonie.

Philip M. White-librarian, Reference Services Department-UNIVERITY OF TEXAS AT AUSTIN.

Gayle A. Williams-monographs cataloger, Latin American Collection-UNIVERSITY of TEXAS AT AUSTIN

\section{RETIREMENTS}

JACK Poolen, chief librarian of the Science Department at Staxford Uviversity: California, retired July 31, after seventeen years at Stanford.

\section{Wyman W. Parker Retires}

A former president of the Association of College and Research Libraries, Wyman W. Parker, has retired from Wesleyan University as Caleb T. Winchester Librarian Emeritus. Forty years a library administrator, at Middlebury College, Kenyon College, the University of Cincinnati and Wesleyan, he will remain active in the library field as a faculty member of the Graduate Division of Library Science of Southern Connecticut State College. He also is an appraiser of books and literary property and is the author of the biography Henry Stevens of Vermont, an American Rare Book Dealer in London, 1845-86, published by N. Israel, Amsterdam, 1963.

\section{University of Chicago Offers Scholarships and Fellowships}

The University of Chicago Graduate Library School will offer scholarships and fellowships for the academic year $1979-80$, for study leading to the M.A. degree, to the Ph.D. degree, or to the Certificate of Advanced Study. Work/study appointments and federally insured loans also are available. Apply before February 1, 1979, to the Dean, Graduate Library School, JRL S-108, the University of Chicago, 1100 E. 57th Street, Chicago, IL 60637. Applicants are considered without regard to race, color, religion, sex, national or ethnic origin, or handicap. 